\title{
Entrepreneurship Education and Entrepreneurial Intention Among Students of Delta State Polytechnic, Ogwashi Uku, Delta State of Nigeria
}

\author{
Hillary O. Odor ${ }^{*} \quad$ Josephine N. Martins-Emesom Casmir O. Bakwuye \\ Department of Business Administration, Delta State Polytechnic, Ogwashi Uku, Delta State, Nigeria
}

\begin{abstract}
The purpose of this paper is to ascertain whether the course, entrepreneurship education is yielding the desired result of enhancing the capabilities of Nigerian graduates by creating in them the right mindset towards creating their own businesses rather than looking for non existing jobs. This is achieved through the analysis of relationship between entrepreneurship education and entrepreneurial intention among students of Delta State Polytechnic, Ogwashi Uku. This study made use of survey research design and was centered on only the final year students of the department of business administration. Data were collected for the study through the administration of structured questionnaires from three hundred and fifty (350) students of which three hundred and forty (340) were retrieved. Data analysis made use of descriptive and inferential statistics. The results from the regression analysis revealed that entrepreneurship education has a positive influence on entrepreneurial intentions of students with $\mathrm{R}$ squared value of $0.751, \mathrm{p}$-value $=0.000$ which implies that 75 percent of the variation in entrepreneurial intentions is explained by variation in entrepreneurship education of students. From the studies, it was also discovered that personality has strong influence on students' intention to venture into businesses after their graduation from school, with an R squared value of 0.737 and a p-value of 0.000 . This informed the rejection of the null hypothesis that personality has no significant influence on entrepreneurship intention of students of Delta state polytechnic to venture into their own businesses after their education. It is therefore a matter of further research to investigate the reasons why graduates find it difficult to complete the AIDA cycle of Awareness, Interest, Desire and Action. Entrepreneurial education has greatly helped to create attention and stimulate both their interest and desire to venture into businesses. What is left is therefore the final push to put into practice what they have learnt.
\end{abstract}

DOI: $10.7176 / \mathrm{EJBM} / 11-20-09$

Publication date:July $31^{\text {st }} 2019$

\section{INTRODUCTION}

The rate of unemployment in Nigeria is very high and the only way to remedy the situation as well as the standard of living for Nigerians is through sustainable development, which can only be achieved through the creation of small and medium scale enterprises. It is expected that the rate of unemployment and poverty in Nigeria should be low considering the various short and long-run measures being taken by the various levels of government in rekindling entrepreneurship, including the compulsory inclusion of entrepreneurship education into the curriculum of tertiary institutions in Nigeria. However, the reverse is the case as the level of unemployment has increased astronomically, leading to a high level of poverty, leading to unprecedented level of crime such as kidnapping, armed robbery, internet fraud, prostitution, child trafficking just to mention a few.

Globally, the issue of entrepreneurship education in university and polytechnics, and the fostering of entrepreneurship activity is increasingly becoming a matter of great concern (Movahedi, Fathi, \& Brijal, 2011). This is undoubtedly true considering the fact that globally, unemployment is rising geometrically and the only solution at this present time is the development of entrepreneurial mindset which will enable Nigerian graduates to set up their own businesses after their education instead of searching for jobs that are non-existent. For instance, unemployment rate in Nigeria increased from 22.70 percent in the second quarter of 2018 to 23.10 percent in the third quarter of 2018. In fact, according to the Bureau of Statistics, unemployment rate in Nigeria averaged 12.31 percent from 2006 until 2018, reaching an all time high of 23.10 percent in the third quarter of 2018 . According to Olayinka (2010) "the greatest challenge confronting Nigerian government today remains massive unemployment which has served as a breeding ground for anti-social vices" (as cited in Ayedun \& Ajayi, 2018, p. 3).

It is also important to note that the standard of education in Nigeria has been declining and the level of unemployment has continued to rise, while the national economy remain stagnant, the tertiary institutions appear to be engaging in unproductive paperwork of teaching rather than in enhancing the motivations and interest in students which will build confidence and enhance the choice of entrepreneurship by young graduates as a career of life.

It is however important to note that the majority of the unemployed are youths, which is composed majorly of the secondary, polytechnic and university graduates. Polytechnics roll out thousands of both National Diploma (ND) and Higher National Diploma (HND) graduates every year with very little or no chance of any gainful 
employment. This makes these graduates to remain at home and engage in unwholesome behaviour. It is empirically wrong to assume that Nigerian youths are lazy, perhaps, what can be assumed is that the youths are dissipating their energies in the wrong directions. Nigerian youths are very intelligent but they are not adequately empowered or rather taught how not to depend on government for employment.

Given that polytechnics are viewed as agents for socio-economic development of any economy, government and indeed policymakers have challenged Nigeria institutions of higher learning, particularly the polytechnics, to intervene by promoting and encouraging student-driven entrepreneurship with the objective of transforming polytechnics into economic hubs of Nigeria.

In 2006 the federal government through the ministry of education directed that entrepreneurship education should be incorporated in all programs offered in our tertiary institutions of learning. The idea behind this is to engender the production of entrepreneurs with superior attitude, skills and abilities that will bring about creativity, innovativeness and enterprise. This in the long run will help to address the problem of unemployment among the youths, reduce the case of restiveness and create wealth among the populace in Nigeria.

Consequently, the National Board of Technical Education and the National Council on Education in collaboration with a consultancy firm engaged in Entrepreneurship education developed the curriculum, teachers guide and training manuals for the teaching of entrepreneurship education in our polytechnics and other tertiary institutions. Entrepreneurship education include: 1. Introduction to Entrepreneurship; 2. Practice of Entrepreneurship; and 3. Entrepreneurship Development. The first two courses are offered at the Ordinary National Diploma level while the third is offered at the Higher National Diploma level. According to Norasmah and Salmah (2009) entrepreneurship is now being considered as the key source of economic survival and innovation in all capitalist economies. Little wonder entrepreneurship education has become a tool that can be used to equip students with a broad range of marketable skills and competencies required to participate in the "real world" of entrepreneurial activities (Wale-Oshiowo, \& Kuye, 2016). It has long been established that tertiary educational system also plays a critical role in identifying and shaping entrepreneurial traits among students (Ibrahim \&Soufani, 2002).

In fact, past studies indicate that one of the key ways of developing entrepreneurial attitudes of both practicing and potential entrepreneurs is domiciled in entrepreneurship education (Liñán et al., 2010). According to WaleOshinowo and Kuye (2016), the role of entrepreneurship education in influencing the transformation of students' intention from seeking white collar job to creating a venture of their own cannot be overemphasized. This is sequel to the fact that research has established that attitude is strongly related to intention $($ Noel, 1998) and inculcation of a range of skills and attributes will definitely lead to entrepreneurial behavioural change among recipients (OECD, 2009). Entrepreneurship education has an important effect on students' intention to establish a new venture (Do Paco, Ferreira, Raposo, Rodrigues \& Dinis, 2011) and it also arouses their interest in the choice of entrepreneurship as a career (Wilson, Kickul \& Marlino, 2007). Little wonder Galloway and Brown (2002) emphasize that entrepreneurship education, especially the type that provides theoretical and practical training, is crucial in enhancing entrepreneurs' creativity and innovative skills in a very dynamic business terrain.

From a critical and elaborate literature analysis, very many studies have been done on the relationship between entrepreneurial education and entrepreneurial intention among university graduates in the developed world, (Linan \& Chen, 2006; Nabi \& Linan, 2011), but only a few that we know, have domiciled their study in a developing economy like Nigeria. This study is therefore aimed at bridging that gap. Hence, the main objective of the current study is to add to the body of research by investigating the relationship between entrepreneurship education and entrepreneurial intention in Delta state Polytechnic. The choice of a polytechnic arose because polytechnic education has always been perceived to offer better practical teaching than university education. Hence many people believe that polytechnic graduates are more practical than university graduates. Whether that is true or not depends on peoples' perception. This paper is arranged in six parts: The first is the introduction followed by the review of related literature. This is followed by the theoretical framework and empirical literature. The next is research methodology, and it is followed by data analysis and discussion of findings. The next is summary, conclusions and recommendations.

\section{LITERATURE REVIEW}

\section{Entrepreneurship Education}

Education has the potential to stimulate the right mind-set in people because it exposes them to variety of academic resources and experienced professionals to drive their thoughts and consequently influence their attention, interest, desires and action (AIDA).

Despite the fact that no universally accepted definition of the term, entrepreneurship has been seen as a process, action or an activity to convert an idea into a value added product or service. Shane and Venkataraman (2000) define entrepreneurship as the discovery, evaluation and exploitation of an opportunity. Meredith, Nelson and Neck (1996) define entrepreneurs as people who have the ability to see and evaluate business opportunities; to gather the necessary resources to take advantage of them; and to initiate appropriate action to ensure success. 
Entrepreneurship education refers to the scope of learning that provides students with entrepreneurial knowledge, skills and abilities required to pursue a career as an independent business owner as against seeking for a paid employment (Keat, Selverajah, \& Meyer, 2011).

Generally speaking, entrepreneurship education is perceived to be a means by which issues affecting the socio-economic lives of a people can be addressed. This is because it is the way to address the current challenge of unemployment, kidnapping, armed robbery, human trafficking and a host of other social vices in Nigeria.

Entrepreneurship education seeks to provide students with the right skills, knowledge and motivations needed to encourage entrepreneurial success in a variety of ventures. It also helps in confronting unemployment, reduce poverty, create wealth, develop self reliance and above all, reduce youth restiveness. EE was introduced into the undergraduate curriculum of the university students in Nigeria in 2006. Over the years, while graduate unemployment has not abated, there is a growing national discontent on the socio-economic relevance of the course in the Nigerian educational system. Entrepreneurship education has been identified as a key success factor that might have an effect on choice of life time career (Peterman \& Kennedy, 2003).

In Nigeria, annually hundreds of thousands of school leavers, university graduates and vocational education and training institutes' graduates enter the job market searching for nonexistent jobs. And in most of the cases they fail. For many, entrepreneurship can be an alternative career choice, provided that prior intention exists. Over the past twenty years, more attention was given to spread entrepreneurship among students.

\section{Entrepreneurial Intention}

The formation, growth and development of entrepreneurship have severally been linked to entrepreneurial intention because it fosters initiative and bring about self reliance (Ayedun, \& Ajayi, 2018). Entrepreneurial intentions can be defined as a state of mind directing and guiding the actions of individuals towards the development and implementation of new business concepts (Bird, 1988). Entrepreneurial intention is viewed as willingness of individuals to perform entrepreneurial behaviour, to engage in entrepreneurial action, to be selfemployed, or to establish new business of their own (Dohse, 2010; Dhose \& Walter, 2012). According to Quan, (2012) entrepreneurial intention can either impulsive or deliberate. The former refers to intention without realistic control of business resources. It can be influenced by personal characteristics, culture or demographic factors. The latter is the willingness of the individual to venture into business due to the feasibility of entrepreneurial behaviours. It depends on external resources such as prior experience or network building.

The intention to engage in certain behaviour are shaped and affected by different factors, such as, needs, values, wants, habits and beliefs (Lee \& Wong, 2004); a set of cognitive variables (Ajzen, 1991) and situational factors (Liñán \& Chen, 2006). This behaviour would be best predicted by the entrepreneurial intentions (Liñán, Rodríguez-Cohard \& Rueda-Cantuche, 2010). Several empirical studies have found out that a person's intention to become an entrepreneur offers the best predictor of his/her actual engagement in entrepreneurship in the future (Hamidi, Wennberg, \& Berglund, 2008).

\section{Impact of entrepreneurial education on entrepreneurial Intention}

The impact of entrepreneurship education is yet to be felt on Nigeria's economy. This can be substantiated by the rising case of unemployment in Nigeria which has led to an escalated increase in the rate of crime and other social vices. Therefore there is a serious and urgent need to investigate the impact of such entrepreneurship education on entrepreneurial intention among students. Going by the rate at which the course entrepreneurship and small business management is taught in our tertiary institution, one will think that the rate of unemployment would have greatly reduced, but reverse is the case. Also, there is need to investigate such factors that can ignite entrepreneurial intention among students so that relevant facilities will be put in place.

For long the Nigeria environment expects their educated young children to seek for paid employment in civil service or even the private sector. This is an indication that the society does not support the entrepreneurial intentions of graduates about to enter into the world of work. Entrepreneurship education was introduced in the polytechnics and universities to encourage undergraduates to have entrepreneurial skills and initiatives, thereby helping to create employments which will at long run transform the economy. Polytechnics need to produce graduates that are self reliant and not job seeking graduates after so much have been imparted to them through entrepreneurship education (Eugene, Adlive \& Agwuibuike, 2013).

Some scholars have highlighted entrepreneurship education as a deterrent factor in proving entrepreneurial intentions of university students and their assessment of entrepreneurial skills (Wang \& Wong, 2004; Goksel \& Aydintan, 2011; Graevenitz, Harhoff \& Weber, 2010; Hill, 2011). The results is a little surprising due to the fact that the concerned students would have obtained more realistic perspectives of what it takes to be successful entrepreneurs, after taking entrepreneurship courses, both at the Ordinary National Diploma and the Higher National Diploma levels. The course content is expected to positively influence the perception of students towards entrepreneurship (Oosterbeek, Praag, \& Ijsselstein, 2010).

A productive educational system is a vital component of a developed economy, but in Nigeria, the educational 
sector has long suffered from neglect, corruption, poor continuity in government and a dearth of qualified personnel. The question that keep surfacing is whether or not the course entrepreneurship education is yielding the desired result, and if not, why?

\section{HYPOTHESIS}

Hypothesis One (H01): Entrepreneurship education has no significant effect on entrepreneurial intentions among students of Delta State Polytechnic, Ogwashi Uku.

Hypothesis Two (H02): Personality characteristics have no influence on entrepreneurial intentions of students of Delta State Polytechnic, Ogwashi Uku.

\section{THEORETICAL FRAMEWORK \\ The Theory of Planned Behaviour}

According to Ajzen (1991), the theory of planned behavior is a link of factors between attitude formation and behavioural exhibitions. The intentions of people predict their deliberate behaviours because almost all of our behaviour is planned. Intention is assumed to take hold of emotional factors that influence behaviour and indicate one's effort to try to perform intentional behaviour. In the context of entrepreneurship, intention is considered as the important tool for setting up a firm (Kantz \& Gartner, 1988) and as a predictor of new reliable enterprise (Krueger, Michael \& Casrud, 2000).

According to Ajzen, entrepreneurial intention is best explained through the use of three antecedents: 1) Attitude toward performing the behaviour; 2) Subjective norm and 3) Perceived behavioural control. Attitude towards the behaviour refers to the degree to which an individual has positive or negative feelings about the behaviour of interest. It entails a consideration of the outcomes of performing the behaviour. Subjective norm refers to the belief about whether significant others think an individual will perform the behavior or not. It relates to a person's perception of the social environment surrounding the behaviour. Perceived behavioural control refers to the individual's perception of the extent to which performance of the behaviour is easy or difficult (Ajzen, 1991). It increases when individuals perceive they have more resources and confidence (Lee \& Kozar, 2005). All other factors are theorised to influence intentions through these three components. Attitude toward performing the behaviours is defined by Ajzen as the perception of an individual or their judgment of performing a particular behaviour, the expected results and the impact of the outcomes. Subjective norm is defined as the individual's viewpoints of the values, thinking, beliefs, and norms held by significant others who have a huge influence on them or whom they really respect (Ajzen, 1991). According to Moriano, Gorgievski, Laguna, Stephan and Zarafshani (2012), normative beliefs concern the perceived probability that important referent individuals or groups will approve or reject a given behaviour. Subjective norms (SN) represents the perception of significant others about a given behaviour. The main assumption for adding this factor to the model is the argument that human behaviour is adopted according to other people's attitude towards a given behaviour. However, because much behaviour pose difficulties of execution that may limit volitional control, it is useful to consider perceived behavioral control, as the third antecedent to intention. To the extent that perceived behavioral control is veridical, it can serve as a proxy for actual control and contribute to the prediction of the behavior in question.

In their respective aggregates, behavioural beliefs produce a favourable or unfavourable attitude toward the behaviour; normative beliefs result in perceived social pressure or subjective norm; and control beliefs give rise to perceived behavioral control. In combination, attitude toward the behaviour, subjective norm, and perception of behavioural control lead to the formation of a behavioral intention. As a general rule, the more favourable the attitude and subjective norm, and the greater the perceived control, the stronger should be the person's intention to perform the behaviour in question. Finally, given a sufficient degree of actual control over the behaviour, people are expected to carry out their intentions when the opportunity arises. Intention is thus assumed to be the immediate antecedent of behaviour. In a nutshell, the theory of planned behaviour postulates that human behaviour is generally guided by three kinds of major beliefs: behavioural beliefs, normative beliefs, and control beliefs. Behavioural beliefs have to do with the likely effects of the behaviour on the person concerned. Normative beliefs have to do with the positive or negative expectations of others towards the behaviour. Control beliefs have to do with the presence of controllable or uncontrollable factors that may favour or hinder the actual performance of that behaviour.

The Theory of Planned Behavior Questionnaire (TPB Questionnaire) assesses each of the theory's major constructs: Attitude, perceived norm, perceived behavioral control, and intention. Seven-point bipolar adjective scales are typically employed.

According to Douglas and Shepherd (2000) people will choose to be entrepreneurs if the total utility they expect to obtain from an entrepreneurial venture, are more than the expected utility from the best employment they can get in the job market. The entrepreneurial utility is defined as benefits derived from income, independence, risk bearing, work effort, and other special benefits that are linked with self-employment. 


\section{Empirical Literature}

Amanamah, Acheapong and Owusu (2018) did an exploratory study of entrepreneurial intention among university students in Ghana, using a survey of 731 undergraduate students. Data were analysed using correlation and multiple regression analysis through the SPSS. Results of standard multiple regressions showed that 6 out of the 23 factors explored in the study significantly influenced student entrepreneurial intention. A follow-up forward regression analysis revealed that exposure to other entrepreneurs was the most significant predictor of student entrepreneurial intentions.

Tsordia, and Papadimitriou (2015) evaluated the role of the theory of planned behaviour on entrepreneurial intention of Greek business students using a sample of 186 students attending the 1st and the 4th year of studies. Besides descriptive statistics, T-test, correlations, and multiple linear regressions were utilized to test hypotheses. The findings revealed that the three components of the theory of planned behaviour seem to play a differentiated role in the formation of the entrepreneurship intentions of business student, with subjective norms proved to be insignificant in the process of intention formation. Furthermore, the role of entrepreneurial curriculum and content was insignificant in influencing the rather weak intentions of business students to pursue a self-employed career. Fourth year students after attending a number of business related courses were found to report on average less strong entrepreneurship intentions compared to the first year students.

Bako, Ajibade, Oluseye, and Aladelusi (2017) explored the entrepreneurial intention of students of Federal Polytechnic, Ilaro in Ogun State, using a sample size of 3000 respondents. The respondents were selected using simple random sampling. Logistic regression model was used for the testing of the hypothesis. The two environmental factors examined were Family environment and Nigeria environment. The impact/significant of these factors were examined to know how they can impact on students entrepreneurship intention. The study revealed that parental entrepreneurship skills directly influence students' entrepreneurial intention and that opportunities that exist in Nigeria affect students' entrepreneurial intention.

Gelderen, Brand, Praag, Bodewes, Poutsma, and Gils (2008) wrote on Explaining entrepreneurial intentions by means of the theory of planned behaviour. The authors set out to present a detailed empirical investigation of the entrepreneurial intentions of business students. The authors employ the theory of planned behaviour (TPB), in which intentions are regarded as resulting from attitudes, perceived behavioural control, and subjective norms. The methodology used was a replication study among samples of undergraduate students of business administration at four different universities (total $n=1,225$ ). Five operationalisations of intentions are used as well as a composite measure. Prior to the main study, qualitative research conducted at two other universities (total $n=373$ ) was held to operationalise the components of the TPB. The results show that the two most important variables to explain entrepreneurial intentions are entrepreneurial alertness and the importance attached to financial security.

Mahendra, Djatmika, and Hermawan (2017) investigate the effect of entrepreneurship education on entrepreneurial intention among college students enrolling in the department of Management, State University of Malang, Indonesia. The research employed descriptive correlation design, and a number of 230 students are taken randomly as sample from 540 students enrolled in three study programs of the university. Path analysis utilizing LISREL 8.50 for windows is used to examine relationships among variables. Research finding revealed that entrepreneurial intention is indirectly affected by entrepreneurship education, meaning that students' entrepreneurial motivation and attitude are two important mediating variables.

Ebewo, Rugimbana and Shambare (2017) study the impact of entrepreneurship education on university students' intentions towards entrepreneurship using a conceptual model supported by the theory of planned behaviour. Data were gathered from 343 final year students at the University of Botswana using a validated Entrepreneurship Intention Questionnaire. The results provide evidence that all three immediate antecedents of entrepreneurial intention; attitude towards entrepreneurship, subjective norm and perceived behavioural control (perceived entrepreneurial abilities) directly influence entrepreneurial intention. Participation in entrepreneurship education was observed to positively influence students' intention to become an entrepreneur by changing their attitude from seeking for paid employment towards entrepreneurship and increasing their entrepreneurial abilities.

Ebewo, Rugimbana and Shambare (2017) study the entrepreneurial intentions of Tshwane University of Technology, Arts and Design students in order to identify what drives students' decision towards self-employment. 150 graduates from the Arts and Design took part in the study and data collected were analysed using structural equation modeling (SEM). The results indicated that subjective norm is an insignificant predictor of entrepreneurial intention compared to attitudes towards entrepreneurial behaviour and perceived entrepreneurial abilities. Attitude towards entrepreneurship as a career option and perceived entrepreneurial abilities of students' both positively influence entrepreneurial intentions.

In the same vein, Muhammad, Aliyu and Ahmed (2015) examine the entrepreneurial intention among students of Abubakar Tafawa Balewa Univesity, Bauchi, Nigeria, using a modified version of the Theory of Planned Behaviour (TPB) as the main framework of examining entrepreneurial intention. A sample size of 205 was drawn from the population and data was analysed using structural equation modeling. The findings show that, 
entrepreneurial attitude, subjective norm and power of behavioural control are all significant predictors of entrepreneurial intention.

Hattab (2014) investigates the impact of entrepreneurship education on the entrepreneurial intentions of university students to start a new venture using Linen's model. The methodological approach involved analysis of a paper and pencil close ended questionnaire distributed to undergraduate students in their last year in a private Egyptian university from three faculties. The findings suggest positive relationship between entrepreneurship education and intentions and perceived desirability while no relation existed with perceived feasibility or self-efficacy.

Ghazali, Ibrahim, and Zainol (2012) undertook a study is to determine and investigate the factors that influence students' perception of their entrepreneurial intention, in order to present the most contemporary future generation of entrepreneurs that can shape the future of the economy and the country. The area of this study covers demographic profiles, attitudinal and behavioural factors, and how these influence the intentions of students to become entrepreneurs. The finding suggests that the female students had significantly higher attitude and social skill and desire to succeed as compared to the male students.

Zain, Akram and Ghani (2010) examine entrepreneurship intention among Malaysian Business Students, using a questionnaire survey on undergraduate business students in a Malaysian public university. The study examines whether business students have an intention to pursue entrepreneurship and whether personality traits and environmental factors influence the students to become entrepreneurs. The results indicate that more than fifty percent of the respondents have an intention to become entrepreneurs and their decisions are attributed by the influence from their family members, academics and attending courses on entrepreneurship. Their findings also revealed that personality traits play a more vital role than environmental factor, in influencing the students' intention to become entrepreneurs.

Suan, Ai, Raman, Loon, and Tanumihardja (2011) study is to examine the entrepreneurial intentions among university students. The study examines the personality traits, family and individual background, education and experience and also perceived desirability. A total of 200 university students took part in this study. It was found that personality traits such as locus of control and the need for achievement had a stronger correlation in comparison with other elements such as education. The background of the student plays an important role as well.

\section{Methodology}

This study used a descriptive survey to explore the relationship between entrepreneurship education and entrepreneurial intention among students of Delta state polytechnic, Ogwashi Uku. In selecting respondents for this study, the focus was on final year students of business administration because they have taken all the courses on Entrepreneurship. Also they are at the most critical decision making point of their career. Therefore examining the effect of the entrepreneurship course offered at the polytechnic on their choice of future career would provide insights on how effective or ineffective the program is towards their decision to open up businesses on their own after graduation. The study population comprises the final year students of Business Administration student of the polytechnic. A total of 350 questionnaires were given to the students to measuring the entrepreneurial intentions of the students.

The questionnaires consists of two parts: The first section of the questionnaire focused on collecting demographic data while the second part deals with the main variables in the research study. Likert scale of 5 points was used from strongly disagree, which represent 1 to strongly agree' which represent 5, to obtain students responses to questions measuring these variables. Questions were constructed on different topics from welldeveloped entrepreneurship curriculum to solicit responses on whether they have been taught; these questions were used to measure entrepreneurship education.

Before the questionnaire was administered, reliability test was conducted on each of the measurement scale using the Cronbach Alpha. The Cronbach's alpha $(\alpha)$ is used to measure the internal consistency and reliability of constructs (Cronbach 1987). Alpha $(\alpha)$ is expressed as a number between 0 and 1 . The results showed the following: for entrepreneurship education $\alpha=0.73$; Entrepreneurial Intention $\alpha=0.78$. These results suggest an internal consistency of these measurement scales and their individual observed variables thereby making the research instrument good and acceptable for this study. Out of the 350 questionnaires, 345 were completed and returned, and out of that 340 had all the data needed for proper analysis. Both descriptive and inferential statistics were adopted for the analysis of data. Descriptive statistics such as frequencies, percentages, mean, standard deviations were used to analyse demographic characteristics of the respondents and other information that was collected from the field. Inferential statistics which include Pearson correlation analysis and linear regression analysis was used was carried out with the use of statistical packages for social science (SPSS) version 22.0.

\section{DATA ANALYSIS}

The results of the descriptive analysis of objective one revealed that out of the total respondents of three hundred and forty (340), three hundred and five (305) of them representing $89.7 \%$ strongly agreed that they have participated in any form of entrepreneurship education. This was also supported by thirty (30) of the respondents 
representing $8.8 \%$ agreeing to have participated in any form of entrepreneurship education. However, only five (5) of the respondents representing $1.5 \%$ disagreed and strongly disagreed with this position. One hundred and ten (110) of the respondents representing $45.8 \%$ strongly agreed, eighty-five (85) of them representing $25 \%$ agreed that they have acquired necessary knowledge to start a business. Eighty four (84) of the respondents representing $24.7 \%$ partially agreed with this. On the other hand, sixty one (51) of the respondents representing $15 \%$ disagreed and nine (10) of the respondents representing $2.9 \%$ strongly disagreed on this question.

Responses on whether entrepreneurship course has given more ideas and opportunities to start a business in the future showed that one hundred and ninety-five (195) of the respondents which represent $57.3 \%$ strongly agreed, eighty eight (88) of the respondents representing $24.7 \%$ also agreed and thirty-four (34) of the respondents representing $10 \%$ partially agreed that entrepreneurship course has given them more ideas and opportunities to start a business in the future. However, only twenty (20) of the respondents representing $8.8 \%$ disagreed with this and three (3) of the respondents representing $0.8 \%$ strongly disagreed. In addition, it was found that one hundred and twenty six (126) of the respondents representing 37\% strongly agreed that entrepreneurship course will be more valuable if they start a business immediately after graduation. Ninety (90) of the respondents representing $26.4 \%$ agreed that entrepreneurship course will be more valuable if they start after graduation. Ninety Five (95) representing $27.9 \%$ partially agreed. However, only eleven (11) and eighteen (18) respondents disagreed and totally disagreed with the question.

Testing of Hypothesis

Hypothesis 1: H0: Entrepreneurship education has no significant effect on entrepreneurial intentions among business administration students of Delta State Polytechnic, Ogwashi-Uku.

Table1. Model summary of Regression Analysis for Entrepreneurial Education and Entrepreneurial Intention

\begin{tabular}{|l|l|l|l|l|}
\hline Model & R & R Squared & Adjusted R Square & $\begin{array}{l}\text { Standard Error of } \\
\text { the Estimate }\end{array}$ \\
\hline 1 & 0.865 & 0.751 & 0.754 & 0.867 \\
\hline
\end{tabular}

a. Predictors: (Constant) Entrepreneurship Education

Source: Researchers field survey, 2019.

Table 2: ANOVAa

\begin{tabular}{|c|c|c|c|c|c|c|}
\hline Model & & Sum of Squares & Degree of Freedom & Mean Squares & $\mathbf{F}$ & Sig. \\
\hline & Regression & 6.435 & 1 & 6.435 & 14.287 & $.000 b$ \\
\hline & Residual & 159.651 & 348 & .442 & & \\
\hline & Total & 166.086 & 349 & & & \\
\hline
\end{tabular}

a. Dependent Variable: Entrepreneurial Intention

b. Predictors: (Constant) Entrepreneurship Education

Source: Researchers' Field Survey, 2019

Table 3: Coefficient of the Regression Model

\begin{tabular}{|l|l|l|l|r|r|}
\hline Model & $\begin{array}{l}\text { Unstandardized } \\
\text { Coefficient (B) }\end{array}$ & $\begin{array}{l}\text { Unstandardized } \\
\text { Coefficient (Standard } \\
\text { Error) }\end{array}$ & $\begin{array}{l}\text { Standardized } \\
\text { Coefficient } \\
\text { (Beta) }\end{array}$ & t & Sig. \\
\hline $\begin{array}{l}\text { (Constant) } \\
\text { Entrepreneurship }\end{array}$ & $\mathbf{3 . 5 8 7}$ & .165 & .708 & $\mathbf{1 9 . 7 2 7}$ & $\mathbf{. 0 0 0}$ \\
\hline Education & .167 & .057 & & $\mathbf{3 . 8 2 8}$ & .000 \\
\hline
\end{tabular}

a. Dependent Variable: Entrepreneurial Intention

Source: Researchers' Field Survey, 2019

Testing Hypothesis 2

Ho2: There is no significant relationship between personality traits and entrepreneurial intention.

Table 4: Model Summary

\begin{tabular}{|l|l|l|l|l|}
\hline Model & $\mathrm{R}$ & $\mathrm{R}$ Squared & Adjusted R Square & Standard Error of the Estimate \\
\hline 1 & $.737 \mathrm{a}$ & .585 & .549 & .535 \\
\hline
\end{tabular}

a: Predictor (Constant)-Personality Traits

Source: Researchers Field Survey, 2019 
Table 5: ANOVA

\begin{tabular}{|c|c|c|c|c|c|}
\hline Model & Sum of squares & $\begin{array}{l}\text { Degree } \\
\text { of freedom }\end{array}$ & Mean Square & $\mathrm{F}$ & Sig. \\
\hline $\begin{array}{l}1 \text { Regression } \\
\text { Residual } \\
\text { Total }\end{array}$ & $\begin{array}{l}72.424 \\
101.523 \\
173.947\end{array}$ & $\begin{array}{l}1 \\
386 \\
387\end{array}$ & $\begin{array}{l}63.757 \\
.372\end{array}$ & 234.887 & $.000 \mathrm{~b}$ \\
\hline
\end{tabular}

a. Dependent Variable: Entrepreneurial Intention

b. Predictors (Constant): Personality Traits Source: Researchers Field Survey, 2019.

Table 6: Coefficient of the Regression Model

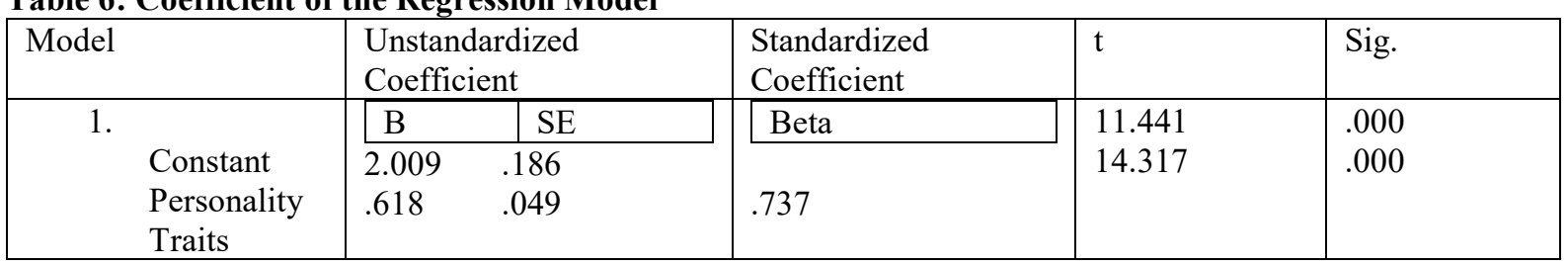

a. Dependent Variable: Entrepreneurial Intention

Source: Researchers Field Survey, 2019.

\section{Discussion}

The analysis of data revealed that entrepreneurship education has a positive influence on entrepreneurial intentions of students of Business Administration of the Delta State Polytechnic Ogwashi Uku. The value of R is a clearly predicts the accuracy of the regression equation. The $\mathrm{R}$ value of 0.865 and $\mathrm{R}$ square value of 0.751 shows that $75.1 \%$ of the variation in entrepreneurial intentions is explained by variation in entrepreneurship education of students. Entrepreneurship education is therefore a good predictor of entrepreneurial intention as can be seen from the data analysis. The result indicated that the $p$ - value was less than the value of significance, that is, $p<0.05$ implying that the model is significant thereby rejecting the null hypothesis that entrepreneurship education has no significant effect on entrepreneurial intentions among students. This emphasized the position of Ayedun and Ajayi (2018) that entrepreneurship education has a positive influence on entrepreneurial intentions of students with $\mathrm{R}$ value of $0.731, \mathrm{p}$-value $=0.000$ which connotes that $73 \%$ of the variation in entrepreneurial intentions is explicitly explained by variation in entrepreneurship education of students.

It also lends support the findings of Tam (2009), knowledge gained through entrepreneurship education has a possibility of increasing students positive attitude towards entrepreneurship.

A linear regression was carried out to test hypothesis II and the results of the regression analysis revealed that personality traits have positive influence on entrepreneurial intentions of students with an $\mathrm{R}$ value of 0.737 and $\mathrm{R}$ value of .585 . The $\mathrm{R}$ value of $58 \%$ shows that $58 \%$ of the variation in entrepreneurial intentions is explained by variation in personality characteristics of students. Personality trait is therefore a good predictor of entrepreneurial intention. Hence, the regression equation could be expressed as: $\mathrm{Y}=2.009+0.737 \mathrm{PT}+0.535$.

The model is significant and therefore good for prediction. The result also indicates that the p-value was less than the value of significance, that is, $p<0.05$ implying that the model is significant thereby rejecting the null hypothesis that personality traits have no significant effect on entrepreneurial intentions among students of Business Administration, Delta State Polytechnic Ogwashi Uku. The findings corroborated the submission of Ayedun and Ajayi (2018) that personality trait is significantly related to entrepreneurial intention. Furthermore it lends support to the study and findings of Muhammad, Aliyu and Ahmed (2015) that, entrepreneurial attitude, subjective norm and power of behavioural control are all significant predictors of entrepreneurial intention.

\section{Conclusion and Recommendations}

This study reveals that the introduction of entrepreneurship education in the tertiary institutions curriculum has to a reasonably extent, increased students' interest and desire in starting their own businesses after graduation from the school. The reasons for the low involvement of graduates into entrepreneurship ventures could therefore be attributed to a variety of reasons having to do with government policies, lack of capital, poor security situation in the country, absence of foreign direct investments, low patronage of locally made products by the government, just to mention a few of them. It will therefore be good if further research could be carried on with a view to actually determining why graduates who have received basic training in entrepreneurship shill lack the courage and power to venture into their own businesses. They rather prefer to search for nonexistent jobs in the public and private sectors. It is also imperative to know that entrepreneurship education has proven to be a stimulator of behaviour through the creation of awareness, interest and desire. What is probably lacking is the last in the AIDA acronym which is in fact the most important, action. 
I recommend a review of the educational policies so that those policies can be made responsive to the social and economic needs of our teaming population. The state of mind that is required of students is that of entrepreneurial awareness, desire, interest and action.

From the findings of this study, it could be recommended that entrepreneurship education should be made compulsory at the secondary school level. This will foster a foundational base for the full blown career mindset at all tertiary institutions of learning in order to expose more youth population to entrepreneurship with the aim of creating more positive perceptions about entrepreneurship and resultant benefits of increased enterprise creations upon graduation. Furthermore, entrepreneurship education should be taught more practically than theoretically given the students opportunity to initiate ideas that can be test run at the micro level.

Just recently, on the working visit of Delta state Governor, Senator Dr Ifeanyi Okowa, he promised to empower a minimum of 50 best graduates in entrepreneurship education in the institution. This is a very welcome development since it will help to bring about healthy competition among the students of the school and therefore reduce the level of unemployment among graduates of the school. It will boost the economy of the state and the multiplier effect is that it will create more jobs for the graduates.

Furthermore, proven entrepreneurs from various fields to give practical talks to students on the importance of setting up one's own business and be one's own master as against searching for white collar jobs that are nonexistent. This will undoubtedly reduce the level of doubts in the minds of students and therefore reduce the psychological inertia that is associated with starting up one's own business.

Government agencies such as the Small Enterprise Development Agency and the Small Enterprise Finance Agency should make student entrepreneurship as one of their core missions. Aggressive campaign through both media and civil society groups are important in militating against the negative perceptions of self - employment. Specifically, forums to showcase exemplary performance of self - employed individuals and their success stories can go a long way in encouraging entrepreneurial intentions among students of the institution. Moreso, curriculum planners, policy makers and educational institutions should pay attention to demographic variables in developing entrepreneurship models in order to come up with initiatives that will have a positive impact on new idea creation and implementation. Furthermore, modernized teaching methods should be introduced with virtual teaching aids in order to facilitate learning and make it an interesting experience. This will help to arouse and developed to increase students' interest in business establishment.

\section{REFERENCES}

Ajzen, I. (1991). The theory of planned behaviour. Organisational Behaviour and Human Decision Processes, $50(2), 179-211$.

Amanamah, R.B., Acheapong, A., \& Owusu, E.K. (2018). An exploratory study of entrepreneurial intention among University students in Ghana. International Journal of Scientific and Technology Research, 7(1), 140148.

Ayedun, T.A. \& Ajayi, M.O. (2018). Entrepreneurial intention among students of selected tertiary institutions in Ondo State. International Journal of Development Strategies in Humanities, Management and Social Sciences, 8(1), 1-16.

Bako, Y.A., Ajibade, I.A., Oluseye, A.B., \& Aladelusi, K.B. (2017). An investigation of entrepreneurial intention among entrepreneurship students in South West Polytechnic students. International Journal of Entrepreneurial Knowledge, 5(2), 16-32.

Bird, B. (1988). Implementing entrepreneurial ideas: The case for intention. Academy of Management Review, 13(3), 442-453.

Dohse, D. A. (2010). The role of entrepreneurship education and regional context in forming entrepreneurial intentions. Working paper presented at Document de Treball de I'IEB.

Dhose, D., \& Walter, S. G. (2012). Knowledge context and entrepreneurial intentions among students. Small Business Economics, 39, 877-895.

Ebewo, P.E., Rugimbana, R., \& Shambare, R. (2017). Effects of entrepreneurship education on students' entrepreneurial intentions: A case of Botswana. Management Studies, 5(4), 278-289.

Gelderen, M., Brand, M., Praag, M., Bodewes, W., Poutsma, E., \& Gils, A. (2008). Explaining entrepreneurial intentions by means of the theory of planned behaviour. Career Development International, 13(6), 538-559.

Ghazali, Z., Ibrahim, N.A., \& Zainol, F.A. (2012). Factors affecting entrepreneurial intention among UniSZA students. Asian Social Science, 9(1), 85-93.

Hamidi, D.Y., Wennberg, K., \& Berglund, H. (2008). Creativity in entrepreneurship education. Journal of Small Business and Enterprise Development, 15(2), 304-320.

Hattab, H.W. (2014). Impact of entrepreneurship education on entrepreneurial intentions of university students in Egypt. The Journal of Entrepreneurship, 23(1), 1-18.

Kamariah, O., Yaacob, A., \& Jamaliah, W. (2004). A study of entrepreneurial intention among young Malaysians: 
A case of Universiti Tenaga Nasional's (UNITEN) students. Proceedings of the $3^{\text {rd }}$ international conference on SMEs in a global economy, MARA Technology University, Malaysia, and University of Wollongong, Australia.

Keat, O.Y., Selvarajah, C., \& Meyer, D. (2011). Inclination towards entrepreneurship among university students: An empirical study of Malaysian university students. International Journal of Business and Social Science. 2(4), 112-129.

Krueger, N.F., Reilly, M.D. \& Carsrud, A.L. (2000). Competing models of entrepreneurial intentions. Journal of Business Venturing, 15 (5/6), 411-432.

Lee, S.H., \& Wong, P.K. (2004). An exploratory study of technopreneurial intentions: A career anchor perspective. Journal of Business Venturing, 19(1), 7-28.

Liñán, F., \& Chen, Y.W. (2006). Testing the entrepreneurial intention model on a two country sample. Document de Treball d'economia dell'empresa, num. 06/7. Universitat Autonoma de Barcelona.

Liñán, F., Rodríguez-Cohard, J.C., \& Rueda-Cantuche, J.M. (2010). Factors affecting entrepreneurial intention levels: A role for education. International Entrepreneurship and Management Journal, 7(2), 195-218.

Mahendra, A.M., Djatmika, E.T., \& Hermawan, A. (2017). The effect of entrepreneurship education on entrepreneurial intention, mediated by motivation and attitude among management students, State University of Malang, Indonesia. International Education Studies, 10(9), 61-69.

Meredith, G.G., Nelson, R.E., \& Neck, P.A. (1996). The practice of entrepreneurship (2nd Impression). Lagos: University Press.

Moriano, J.A., Gorgievski, M., Laguna, M., Stephan, U., \& Zarafshani, K. (2012). A cross-cultural approach to understanding entrepreneurial intention. Journal of career development, 39(2): 162-185.

Movahedi, R., \& Fathi, H. (2011). Assessing agricultural students' attitude towards entrepreneurship. International Journal of Agriculture: Research and Review, 1(4), 168-173.

Muhammad, A.D, Aliyu, S., \& Ahmed, S. (2015). Entrepreneurial intention among Nigerian university students. American Journal of Business Education, 8(4), 239-248.

Nabi, G., \& Liñán, F. (2011). Graduate entrepreneurship in the developing world: Intentions, education and development. Education \& Training, 53(5), 325-334.

Norasmah, H.O. \& Salmah, B.I. (2009), Attitude Towards Choosing a Career in Entrepreneurship Amongst Graduates, European Journal of Social Sciences, Vol. 10, no. 3, pp. 419-434.

Oosterbeek, H., Praag, M. C. V., \& Ijsselstein, A. (2010). The impact of entrepreneurship competencies and intentions. Tinbergen Institute Discussion Paper, University of Amsterdam.

Peterman, N. E. \& Kennedy, J. (2003). Enterprise education: influencing students' perceptions of entrepreneurship. Entrepreneurship Theory and Practice, 28(2), 129-144.

Quan, X. (2012). Prior Experience, social network and levels of entrepreneurial intentions. Management Research Review, 35, 945-957.

Salmah T. (2006), Fostering Entrepreneurship: A Challenge for an Educational Institution, The $2^{\text {nd }}$ National Entrepreneurship Conference Proceedings, Vistana, Pulau Pinang, 9 - 10 December.

Shane, S., \& Venkataraman, S. (2000). The promise of entrepreneurship as a field of research. Academy of Management Review, 25(1), 217-226.

Suan, C.T., Ai, Y.J., Raman, K., Loon, K.W., \& Tanumihardja, J. (2011). Entrepreneurial intentions among university students. Business \& Management Quarterly Review, 2(3), 33-38.

Tam, H. W. (2009). How and to what extent does entrepreneurship education make students more entrepreneurial? Doctor of Philosophy Dissertation, University of California. Santa Barbara.

Tsordia, C., \& Papadimitriou, D. (2015). The Role of Theory of Planned Behavior on Entrepreneurial Intention of Greek Business Students International Journal of Synergy and Research, 4(1), 23-37.

Wale-Oshiowo, B.A., \& Kuye, O.L. (2016). The influence of entrepreneurship education and knowledge on entrepreneurial intention -An empirical study of final year Yaba College of Technology students. Nigerian Journal of Management Studies, 16(1), 174-190.

Wang, C. K., \& Wong, P. K. (2004). Entrepreneurial interest of University students in Singapore. Technovation, 24, 163-172.

Zain, Z.M., Akram, A.M., \& Ghani, E.K. (2010). Entrepreneurship intention among Malaysian business students. Canadian Social Sciences, 6(3), 34-44. 